\title{
Screening of worldwide cowpea collection to drought tolerant at a germination stage
}

\author{
Márcia Carvalho $^{\mathrm{a}}$, Manuela Matos ${ }^{\mathrm{b}, \mathrm{c}}$, Isaura Castro ${ }^{\mathrm{a}, \mathrm{b}}$, Eliana Monteiro ${ }^{\mathrm{b}}$, Eduardo Rosa ${ }^{\mathrm{a}}$, \\ Teresa Lino-Neto ${ }^{\mathrm{d}, *}$, Valdemar Carnide ${ }^{\mathrm{a}, \mathrm{b}}$ \\ ${ }^{a}$ Centre for Research and Technology of Agro-Environment and Biological Sciences (CITAB), University of Trás-os-Montes and Alto Douro (UTAD), 5000-801, Vila Real, \\ Portugal \\ ${ }^{\mathrm{b}}$ Department of Genetics and Biotechnology, University of Trás-os-Montes and Alto Douro (UTAD), 5000-801, Vila Real, Portugal \\ ${ }^{\mathrm{c}}$ Biosystems \& Integrative Sciences Institute (BioISI), Sciences Faculty, University of Lisbon, Campo Grande, 1749-016, Lisbon, Portugal \\ ${ }^{\mathrm{d}}$ Biosystems \& Integrative Sciences Institute (BioISI), Plant Functional Biology Center (CBFP), University of Minho, Campus de Gualtar, 4710-057, Braga, Portugal
}

\section{A R T I C L E I N F O}

\section{Keywords:}

Vigna unguiculata L. Walp.

Drought stress

Seed germination

Seedling growth

Proline determination

\begin{abstract}
A B S T R A C T
Global warming has an increasing impact on the availability of water for agriculture. Crops tolerant to high temperatures and drought, such as cowpea (Vigna unguiculata L. Walp.), have an added value in the near future. The main objective of this study was to evaluate the effect of drought on seed germination and seedling emergence of cowpea genotypes, in order to screen the most tolerant genotypes. Seeds from 58 cowpea genotypes all over the world were submitted to two stress conditions, induced by PEG-6000 (corresponding to osmotic potentials of -0.75 bars and -1.5 bars). Germination and seedling growth parameters, vigor index and proline content were determined to assess drought tolerance. The results revealed significant differences of all parameters among genotypes after treatments and interaction of both. Water stress caused a general decrease in germination and seedling growth, while an increase in proline content was observed. A high variation of drought responses were detected among genotypes, being possible to select seven genotypes (C11, C18, C44, C46, C47, C50 and C54) as tolerant to drought at germination stage. These results will be useful to select the best suitable parents for insertion in future breeding programs.
\end{abstract}

\section{Introduction}

Worldwide agricultural production has been limited by several environmental constraints in the form of abiotic stresses, which affects plants growth, metabolism and development (Eftekhari et al., 2017; Muscolo et al., 2014). Water scarcity is currently one of the most severe limitations of plant development and production (Eftekhari et al., 2017; Jain and Saxena, 2016). The predicted temperature increase and rainfall decrease will be responsible for more frequent drought periods, mainly in the Mediterranean region including the Iberian Peninsula (Kröner et al., 2017). In this climate change scenario, the selection of drought-tolerant plants gain more importance, particularly the selection during germination. Some studies report several physiological characteristics (including seed germination and seedling growth) as indicators of drought tolerance in specific crop genotypes (Bouslama and Schapaugh, 1984; Steiner et al., 2017; Yan, 2015). Seed germination and seedling emergence are potentially the most critical stages susceptible to water stress (Ahmad et al., 2009; Hellal et al., 2018; Li et al., 2011, 2015) and are pivotal steps for crop propagation (Ravelombola et al., 2017). Indeed, water limitation can be responsible for the decline or even complete inhibition of seedling emergence and stand establishment (Kaya et al., 2006; Wu et al., 2011; Yan, 2015). However, tolerance against drought during the germination stage allow an uniform plant stand (Steiner et al., 2017).

Cowpea (Vigna unguiculata L. Walp.) is a grain legume with high worldwide economic importance, originated in Africa. Seeds of this legume are an important source of protein and other nutritional components for human diet (Ravelombola et al., 2017; Timko and Singh, 2008) and also an important source to animal fodder (Huang et al., 2012). Like many legumes, cowpea has the ability to fix atmospheric nitrogen through rhizobium symbiosis (Ehlers and Hall, 1996) and is easily grown in low fertility soils (Eloward and Hall, 1987). Some

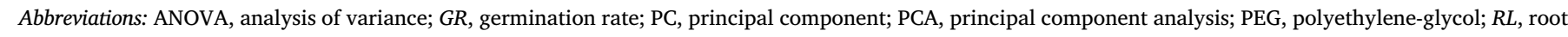
length; SE, standard error; $S L$, shoot length; VI, vigor index; $\% G$, germination percentage

* Corresponding author.

E-mail address: tlneto@bio.uminho.pt (T. Lino-Neto). 
reports referred to the ability of cowpea to grow in regions without irrigation and irregular rainfall, being considered as one of the most tolerant legumes to drought (Agbicodo et al., 2009). Taking into consideration the upcoming climate change and increasing protein needs, all these advantages make desirable to increase cowpea production and consumption in European Union. Nowadays, almost all consumed cowpea in Europe is imported from African countries (FAOSTAT, 2018). The establishment success of this crop in such semiarid regions depends on the fast and uniform seed germination under low water availability (Muscolo et al., 2014).

Several methods and efforts have been employed to identify drought tolerant varieties in different crops (Darkwa et al., 2016; Muscolo et al., 2014), including in cowpea (Jain and Saxena, 2016; Muchero et al., 2009). Some studies referred that an in vitro screening method based on polyethylene-glycol (PEG) is suitable for selecting tolerant genotypes able to germinate under drought stress conditions (Jain and Saxena, 2016; Kocheva and Georgiev, 2003; Muscolo et al., 2014; Ravelombola et al., 2017) being a good alternative method to field experiments (Steiner et al., 2017). Indeed, the PEG polymer has been used to mimic drought stress effects in plants with limited metabolic interferences (Murillo-Amador et al., 2002). Another important and appropriate methodology for determining drought tolerance levels is proline determination. The accumulation of osmolytes is a plant protection strategy against abiotic stress (Mafakheri et al., 2010). Proline accumulation is one of the first plant responses to water-deficit stress, in order to reduce injury to cells (Anjum et al., 2011). In general, proline concentration has been considered a good indicator of drought tolerance, as higher levels are detected in stress-tolerant plants when compared to susceptible ones (Toscano et al., 2016).

Recently, germination and growth responses to drought stress have been reported in several crops, including legume crops as chickpea (Cicer arietinum L.; Dharanguttikar et al., 2015), common bean (Phaseolus vulgaris L.; Machado Neto et al., 2006), lentil (Lens culinaris Medik.; Muscolo et al., 2014) and soybean (Glycine max L. Merr.; Kpoghomou et al., 1990; Vieira et al., 1991). In general, these studies indicated a delay in initial germination and a reduction in the different germination parameters due the low water potential. Until now, few studies regarding cowpea seed germination in drought stress conditions have been developed. This is the first report of cowpea germination under drought conditions and makes use of a large set cowpea seeds from Iberian Peninsula and also from worldwide countries. The main objectives of this work are (1) the evaluation of cowpea responses to drought stress during germination, and (2) the screening of droughttolerant cowpea genotypes from a world-wide collection. Besides the understanding of mechanisms involved in germination under drought stress, the results will be useful for selecting the best genotypes for enhancing the production of this grain legume in Southern Europe (Iberian Peninsula).

\section{Materials and methods}

\subsection{Plant material}

A total of 58 cowpea (Vigna unguiculata L. Walp.) genotypes were used for drought tolerance evaluation at germination stage (Table 1) being 29 from Iberian Peninsula, 26 originally collected from 17 different worldwide countries and three used as reference. In a previous study, the majority of the cowpea genotypes were already characterized using single nucleotide polymorphism (SNP) through the Illumina Cowpea iSelect Consortium Array (Carvalho et al., 2017b). Some of the Iberian Peninsula cowpea genotypes were also characterized through the morphological and agronomical parameters (Carvalho et al., 2017a). The references displayed different levels of drought tolerance: Bambey 21 (highly susceptible), CB46 (moderately susceptible) and IT93K-503-1 (highly tolerant), as described by Hamidou et al. (2007) and Muchero et al. (2008, 2010).
Table 1

Cowpea genotypes used in this study with reference to their origin (city and country, when available) and current status.

\begin{tabular}{|c|c|c|}
\hline Code & Origin & Status \\
\hline $\mathrm{C} 1$ & Ferreira do Alentejo, Portugal & Landrace \\
\hline $\mathrm{C} 2$ & Ansião, Portugal & Landrace \\
\hline C3 & Évora, Portugal & Landrace \\
\hline $\mathrm{C} 4$ & Mértola, Portugal & Landrace \\
\hline $\mathrm{C} 5$ & Abrantes, Portugal & Landrace \\
\hline C6 & Almeida, Portugal & Landrace \\
\hline C7 & Figueira Castelo Rodrigo, Portugal & Landrace \\
\hline $\mathrm{C} 8$ & Pinhel, Portugal & Landrace \\
\hline C9 & Meda, Portugal & Landrace \\
\hline $\mathrm{C} 10$ & Trancoso, Portugal & Landrace \\
\hline C11 & Macedo de Cavaleiros, Portugal & Landrace \\
\hline $\mathrm{C} 12$ & Penamacor, Portugal & Landrace \\
\hline $\mathrm{C} 13$ & Sabugal, Portugal & Landrace \\
\hline $\mathrm{C} 14$ & Mogadouro, Portugal & Landrace \\
\hline $\mathrm{C} 15$ & Portugal & Variety \\
\hline $\mathrm{C} 16$ & Granada, Spain & Landrace \\
\hline $\mathrm{C} 17$ & Malaga, Spain & Landrace \\
\hline $\mathrm{C} 18$ & Malaga, Spain & Landrace \\
\hline C19 & Orense, Spain & Landrace \\
\hline $\mathrm{C} 20$ & Girona, Spain & Landrace \\
\hline $\mathrm{C} 21$ & Baleares, Spain & Landrace \\
\hline $\mathrm{C} 22$ & Caceres, Spain & Landrace \\
\hline $\mathrm{C} 23$ & Pontevedra, Spain & Landrace \\
\hline $\mathrm{C} 24$ & Huelva, Spain & Landrace \\
\hline $\mathrm{C} 25$ & Jaen, Spain & Landrace \\
\hline $\mathrm{C} 26$ & Badajoz, Spain & Landrace \\
\hline $\mathrm{C} 27$ & Albacete, Spain & Landrace \\
\hline $\mathrm{C} 28$ & Zamora, Spain & Landrace \\
\hline $\mathrm{C} 29$ & Cordoba, Spain & Landrace \\
\hline C30 & Sicilia, Italy & Landrace \\
\hline C31 & Puglia, Italy & Landrace \\
\hline $\mathrm{C} 32$ & Cuneo, Italy & Landrace \\
\hline C33 & Italy & Landrace \\
\hline C34 & Italy & Landrace \\
\hline C35 & Italy & Landrace \\
\hline C36 & Greece & Landrace \\
\hline C37 & Greece & Landrace \\
\hline C38 & Greece & Landrace \\
\hline C39 & Creta, Greece & Landrace \\
\hline $\mathrm{C} 40$ & Nigeria & Cultivar \\
\hline $\mathrm{C} 41$ & Angola & Landrace \\
\hline $\mathrm{C} 42$ & Benin & Landrace \\
\hline $\mathrm{C} 43$ & Egy & Landrace \\
\hline $\mathrm{C} 44$ & Ghana & Landrace \\
\hline $\mathrm{C} 45$ & Senegal & Landrace \\
\hline $\mathrm{C} 46$ & Zambia & Cultivar \\
\hline $\mathrm{C} 47$ & Iran & Landrace \\
\hline $\mathrm{C} 48$ & Irak & Landrace \\
\hline $\mathrm{C} 49$ & Cuba & Landrace \\
\hline C50 & Congo & Landrace \\
\hline C51 & China & Landrace \\
\hline C52 & India & Landrace \\
\hline C53 & Brazil & Cultivar \\
\hline C54 & Bulgaria & Landrace \\
\hline C55 & China & Landrace \\
\hline \multicolumn{3}{|l|}{ References } \\
\hline Bambey21 & Senegal & Cultivar \\
\hline CB46 & California, USA & Cultivar \\
\hline IT93K-503-1 & Nigeria & Breeding line \\
\hline
\end{tabular}

\subsection{Determination of optimal PEG concentration}

A pilot experiment was performed in order to determine the optimal polyethylene glycol 6000 (PEG-6000) concentration for cowpea seed germination studies. Three cowpea genotypes (C8, C15 and C40) were tested under four PEG-6000 (Merk Millipore, Germany) concentrations, corresponding to final osmotic potentials of $-0.75,-1,-1.5,-2$ bars. Germination assays (six days) were performed in an incubator (Binder incubator series D, Germany) in the dark. The temperature was set for $26 \pm 1{ }^{\circ} \mathrm{C}$, as previous results showed that cowpea genotypes 
had the highest seed germination rate at this temperature (data not shown), which is also in agreement with the optimal temperature reported by Jain and Saxena (2016). Uniform seeds from each cowpea genotype were selected and sterilized for about $3 \mathrm{~min}$, in a $10 \%$ sodium hypochlorite solution, to prevent fungal growth. Seeds were then washed with sterile distilled water for about $3 \mathrm{~min}$, four times. Following the description of Jain and Saxena (2016), ten seeds from each genotype were germinated on a two-folded filter paper, placed in a Petri dish (diameter $11 \mathrm{~cm}$ ), containing $14 \mathrm{~mL}$ of PEG-6000 solutions. Distilled water (without PEG-6000) was used as control. Each Petri dish was sealed with Parafilm to avoid evaporation and contaminations. Three replicates of each treatment/genotype combination were performed. Cowpea drought tolerance was evaluated by seed germination rate.

\subsection{Germination conditions and experimental design}

Germination assays with all cowpea genotypes were performed as previously described from December 2017 to February 2018. Drought stress was induced by two different PEG-6000 concentrations, corresponding to final osmotic potentials of -0.75 and -1.5 bars (hereinafter referred to as stress 1 and 2, respectively). Three replicates of each treatment/genotype combination were performed and separately placed on three different incubator shelves (each shelf was considered as a block). The experiment was run multiple times due to space limitations. After each run, the incubator was sprayed with $75 \%$ ethanol solution to limit any microbial growth and contamination.

\subsection{Measurements and data collection}

A seed was considered germinated if the radicle had one-third of seed length, as described by Ravelombola et al. (2017). The number of germinated seeds was daily recorded for six days. At the end, the seed germination percentage $(\% G)$ was calculated and the roots and shoots length of five plants was measured ( $R L$ and $S L$, respectively) and the plants were discarded. Seed germination rate $(G R)$ was calculated using the formula $G R=\sum_{t i}^{n i}$ proposed by Silva and Matos (2016), where $n i$ is the number of seeds germinated on each observation day and $t i$ is the observation day. The vigor index $(V I)$ was also calculated following the formula presented by Abdul-Baki and Anderson (1973), $V I=(M R L+M S L) \times \% G$, where $M R L$ is the mean of root length and $M S L$ is the mean of shoot length.

\subsection{Proline determination}

For free proline content determination, the roots of five seedlings were frozen in liquid nitrogen and ground to a fine powder. Root tissue ( $40 \mathrm{mg}$ ) was homogenized in $1 \mathrm{~mL}$ of $3 \%(\mathrm{w} / \mathrm{v})$ sulfosalicylic acid and centrifuged at $12,000 \mathrm{~g}$ for $20 \mathrm{~min}$, according to Bates (1973) with some modifications. After centrifugation, the supernatant $(0.1 \mathrm{~mL})$ was mixed with $0.4 \mathrm{~mL}$ of acid-ninhydrin and $0.4 \mathrm{~mL}$ of glacial acetic acid. The resulting mixture was heated for $1 \mathrm{~h}$ at $100^{\circ} \mathrm{C}$ in a water bath. After reaction interruption by placing the tubes on ice, toluene $(0.8 \mathrm{~mL})$ was added and vigorously mixed. The toluene phase (upper phase) absorbance was read at $520 \mathrm{~nm}$, using a spectrophotometer (PowerWave XS2, BioTek Instruments, Inc., Winooski, USA). Free proline content was estimated by referring to a standard curve using L-proline and expressed as $\mu \mathrm{g}$ proline/mg of fresh tissue. Each sample of each combination (treatment/genotype) was used for three technical repetitions.

\subsection{Data analysis}

Data from germination ( $\% G, G R$ and $V I$ ) are presented as the mean of three independent assays $(n=3)$ ). Growth measurements (root and shoot length) and free proline content were performed from five plants per each plate $(n=15)$ and are presented as the mean of 15 repetitions. Before performing the ANOVA, all measurement data were tested for normality, according to the Kolmogorov-Smirnov and Kruskal-Wallis tests, and homogeneity with the Levene test. Non-homogeneity data were observed in germination percentage, being the data transformed with the formula $\arcsin \sqrt{(\% G / 100)}$ to obtain homogeneity. Differences between means were analyzed with one-way and two-way ANOVA followed by Tukey's test ( $p<0.05$ was considered significant), using IBM SPSS Statistics version 20 software (IBM SPSS, Inc., Chicago, USA). The statistical significance in mean values among genotypes was examined with Tukey's multiple comparisons tests after two-way ANOVA using the GraphPad Prism version 7.01 software (GraphPad, Inc., California, USA). Principal component analysis (PCA) was performed using Past version 3.19 statistical software (Hammer et al., 2001). The used values were normalized into percentage, taking into account the maximum value obtained from each assay, and was calculated by the ratio of stress 2 and control.

\section{Results}

\subsection{Determination of optimal PEG conditions}

A preliminary experiment was performed with the aim to select those PEG-6000 concentrations more suitable for screening cowpea (Vigna unguiculata L. Walp.) tolerance to drought at a germination stage. Four PEG-6000 concentrations were chosen based on their osmotic potential $(-0.75,-1,-1.5$ and -2 bars). In the three tested cowpea genotypes, a germination rate decrease with increasing water stress imposition through PEG-6000 was detected (Fig. 1). For the most severe stress condition ( -2 bars), a low seed germination rate was detected, not allowing to discriminate the most susceptible genotypes. For this reason, the use of such PEG-6000 concentration could make difficult to screen the most susceptible genotypes. When imposing osmotic potentials of -0.75 and -1.5 bars, a better genotype discrimination was obtained. As one-way ANOVA revealed significant differences among cowpea genotypes $(F=27.219$ and 9.296, $p=$ 0.001 and 0.015 , respectively; Supplementary file 1), these osmotic potentials were further used for determining the drought tolerance level of a set of 55 cowpea genotypes and three references.

\subsection{Drought effect on seed germination and growth parameters}

The drought tolerance level of cowpea genotypes was firstly assessed by determination of $\% G, G R, R L, S L$ and VI (Table 2; Supplementary file 2). For all evaluated parameters, no significant differences $(p>0.05)$ between replicas were observed.

The seed germination percentage decreased with increasing severity of drought in $50 \%$ of the evaluated cowpea genotypes, although only three genotypes (C10, IT93K-503-1 and Bambey 21) presented significant differences $(p<0.05$; Table 2; Supplementary file 2). The germination (\%) of the remaining 50\% genotypes was not affected even under severe drought treatment (Table 2). The differences between cowpea genotypes were indeed significant $(p<0.001$; Table 3$)$, which could be partially related with variations on germination capacity of each genotype (even under control conditions; Table 2). Considering all genotypes together, the differences between stress treatments revealed to be significant ( $p<0.01$; Table 3 ), suggesting that drought stress imposition affects seeds germination of cowpea. Besides the percentage of germinated seeds, the germination rate is considered as one of the most informative parameters in this type of studies. A drop in germination rate was observed when seeds were exposed to drought stress (Table 2), revealing that seeds take more time to germinate when subjected to drought. This result is also in accordance with the detected reduced germination percentage. Significant differences $(p<0.001)$ were also detected between treatments (control and drought stresses) and among genotypes (Table 3). While some genotypes presented a dramatically decrease on germination rate $(p<0.001)$ with increase of drought stress, others did not reveal significant differences $(p>$ 


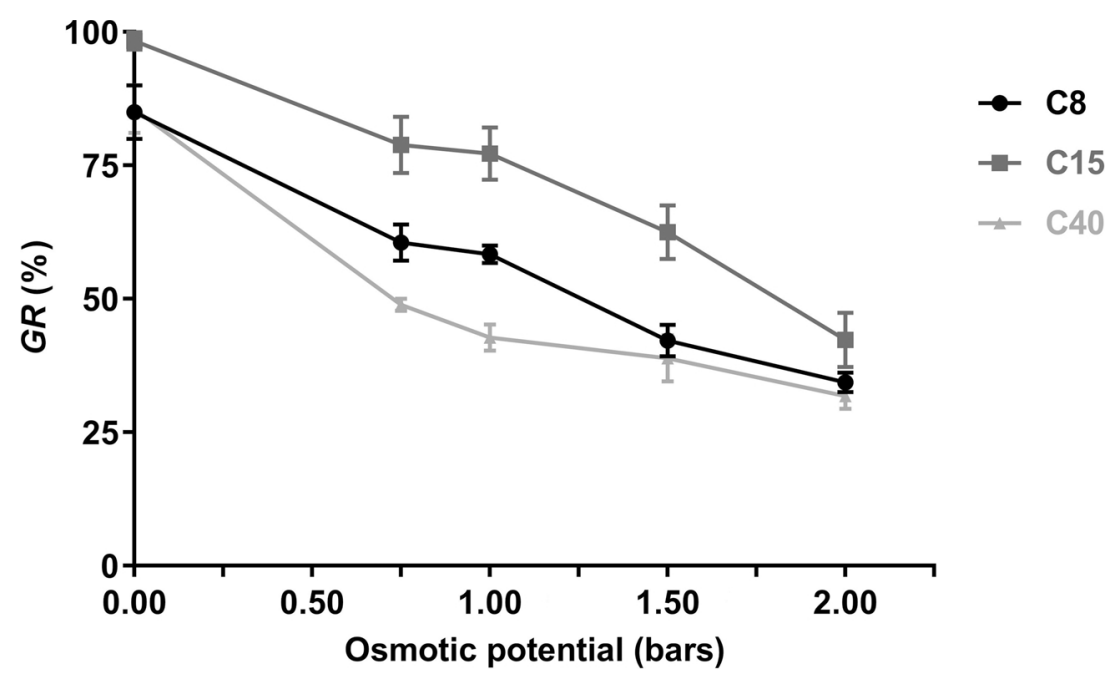

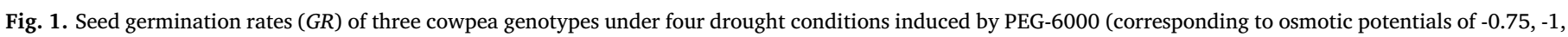
-1.5 and -2 bars $)$ and control (0 bars) with water $(n=3)$.

0.05) between treatments (Table 2).

The results also showed the commitment of seedling emergence with drought stress imposition, since root and shoot growth were generally inhibited under drought stress treatments (Table 2). Indeed, both parameters were significantly $(p<0.001)$ affected by drought stress treatments and genotypes presented significant differences for both parameters ( $p<0.001$; Table 3$)$. A decrease in the root length was generally detected (by the means of all genotypes) when compared to control (23\% and $30 \%$, for stress 1 and 2, respectively). Many cowpea genotypes did not show variations in the root length with drought stress, but four genotypes in particular (C6, C20, C25 and Bambey 21) were significantly affected. Similarly, a reduction in shoot length was registered in many cowpea genotypes, corresponding to general decreases (means of all genotypes) of $41 \%$ and $59 \%$ (for stress 1 and 2, respectively) in relation to control. Interestingly, many genotypes that were significantly affected in their root length, were not significantly affected in their shoot length. This result suggests that root length is more sensitive to drought conditions than shoot length.

As germination and seedling emergence may interfere with plant vigor and ultimately with crop yields, the vigor index was also determined (Table 2). The vigor index decreased significantly $(p<$ 0.001 ) with drought severity and among genotypes (Table 3). However, while many genotypes were significantly affected $(p<0.001)$ by drought stress, some were not affected $(p>0.05)$. The genotypes C11, C54 and IT93K-503-1 (highly tolerant reference) increased their vigor under drought stress conditions (Table 2).

\subsection{Drought effect on proline accumulation}

Free proline content, in general (means of all genotypes), increased 1.4-fold (stress 1) and 1.7-fold (stress 2) in relation to control condition (Table 4). Differences between stress treatments were significant $(p<$ 0.01 ; Table 3 ), suggesting that drought stress imposition induces the production of proline in roots. The highest increase of proline was detected in several genotypes, including the tolerant IT93K-503-1 genotype, while others did not reveal significant differences in proline content with drought stress imposition (Table 4; Supplementary file 2). The highly susceptible reference (Bambey 21) genotype had, in all treatments, the lowest proline content (Table 4).

\subsection{Screen of genotypes to drought tolerance}

Different development measures and proline accumulation, evaluated in the most severe stress condition (stress 2), were normalized in relation with control conditions and used for discriminating cowpea genotypes tolerance/susceptibility with a principal component analysis (PCA; Fig. 2). First two principal components of PCA explained $97.52 \%$ of total variation ( $\mathrm{PC} 1=88.75 \%$ and $\mathrm{PC} 2=8.77 \%$ ), being proline (PC1, 0.99) and vigor index and root length (PC2, 0.64) the three most contributive parameters. PCA clustered the genotypes C18, C46, C47, $\mathrm{C} 50$, and in particular C44, close to the tolerant reference IT93K-503-1. On the other hand, the C3 and C9 genotypes were grouped close to the susceptible reference genotype Bambey 21. C11 and C54 genotypes, which presented enhanced responses to drought stress, are distant from the remaining genotypes, suggesting a different performance than other genotypes.

\section{Discussion}

One of the most serious limitations to crops yield is drought. This multifaceted stress condition is differently sensed by plants depending on their growth stage, stress duration and severity (Ahmad et al., 2009). Drought stress during germination can impose a critical limitation to plant development, mainly because seed germination is the most sensitive stage in plant life cycle (Ahmad et al., 2009; Hellal et al., 2018; Muscolo et al., 2014). When seeds are exposed to water stress (or to other unfavorable environmental condition), plants establishment can be compromised (Ahmad et al., 2009; Muscolo et al., 2014). The selection of cowpea (Vigna unguiculata L. Walp.) genotypes with increased seed tolerance to drought is a reasonable strategy for the selection of accessions for enhancing cowpea production in a climate change scenario. The use of an in vitro screening method on seeds, where drought imposition was artificially imposed by PEG-6000, allowed the assay of 58 cowpea genotypes, which were compared with three susceptible/ tolerant genotypes. A wide range of PEG-6000 osmotic potentials was initially tested and presented a dose-dependent detrimental effect on seed germination. This polymer adversely affected the germination and seedling growth of cowpea genotypes, as observed in previous studies (Khodarahmpour, 2011). PEG-6000 concentrations corresponding to osmotic potentials of -0.75 and -1.5 bars were considered adequate to induce stress for the cowpea, while displaying discriminatory resolution among cowpea genotypes. For this reason, both PEG-6000 concentrations were used for imposing drought stress conditions and evaluate the most tolerant drought genotypes.

Considering that tolerant genotypes have higher capacity to germinate and emerge from seeds than susceptible ones, the obtained results could indicate which are the most susceptible and tolerant cowpea genotypes. Previous results obtained under different drought stress 
Table 2

Germination and seedling emergence parameters in the 58 studied cowpea genotypes under drought stress conditions. For reference, maximum, minimum, mean, Fvalue and Tukey's test (significance level of 0.05 ) values are indicated. Means were analysed with one-way ANOVA followed by Tukey's test (significance level of $0.05)(n=3$ to $\% G$, GR and $V I$ and $n=15$ to $R L$ and $S L)$.

\begin{tabular}{|c|c|c|c|c|c|c|c|c|c|c|c|c|c|c|c|}
\hline \multirow{2}{*}{ Code } & \multicolumn{3}{|c|}{$\% G$} & \multicolumn{3}{|c|}{$G R$} & \multicolumn{3}{|c|}{$R L$} & \multicolumn{3}{|c|}{$S L$} & \multicolumn{3}{|c|}{$V I$} \\
\hline & Control & Stress 1 & Stress 2 & Control & Stress 1 & Stress 2 & Control & Stress 1 & Stress 2 & Control & Stress 1 & Stress 2 & Control & Stress 1 & Stress 2 \\
\hline $\mathrm{Cl}$ & 100 & 100 & 93.33 & 0.63 & 0.34 & 0.29 & 11.5 & 8.89 & 7.11 & 5.25 & 1.79 & 1.13 & 1675.00 & 1067.78 & 764.00 \\
\hline $\mathrm{C} 2$ & 100 & 100 & 86.67 & 0.76 & 0.56 & 0.36 & 8.57 & 6.58 & 5.11 & 4.15 & 1.94 & 1.39 & 1271.94 & 852.22 & 568.89 \\
\hline $\mathrm{C} 3$ & 100 & 100 & 93.33 & 0.64 & 0.4 & 0.34 & 11.51 & 7.24 & 5.93 & 4.02 & 2.28 & 1.53 & 1553.33 & 951.83 & 699.78 \\
\hline $\mathrm{C} 4$ & 100 & 100 & 100 & 0.8 & 0.43 & 0.47 & 15.59 & 8.2 & 7.24 & 7.74 & 2.98 & 1.98 & 2332.78 & 1118 & 921.67 \\
\hline C5 & 100 & 100 & 100 & 0.56 & 0.39 & 0.33 & 12.89 & 8.83 & 6.38 & 5.78 & 2.36 & 1.43 & 1866.67 & 1119.44 & 780.83 \\
\hline C6 & 100 & 73.33 & 66.67 & 0.67 & 0.29 & 0.23 & 13.86 & 5.81 & 5.75 & 7.87 & 1.03 & 1.75 & 2172.61 & 502.83 & 504 \\
\hline $\mathrm{C} 7$ & 100 & 93.33 & 100 & 0.73 & 0.43 & 0.33 & 13.52 & 8.84 & 7.99 & 7.09 & 3.17 & 2.03 & 2060.67 & 1093.33 & 1002.22 \\
\hline C8 & 100 & 93.33 & 80 & 0.7 & 0.41 & 0.28 & 13.64 & 9.28 & 8.06 & 5.83 & 2.34 & 1.89 & 1947.78 & 1096.67 & 811.11 \\
\hline C9 & 100 & 93.33 & 86.67 & 0.8 & 0.41 & 0.33 & 16.6 & 11.24 & 10.51 & 6.67 & 3.47 & 2.01 & 2327.17 & 1349.44 & 1074.67 \\
\hline $\mathrm{C} 10$ & 80 & 93.33 & 53.33 & 0.33 & 0.31 & 0.16 & 11.16 & 7.91 & 7.22 & 4.49 & 3.24 & 1.44 & 1252.44 & 1057.5 & 458.44 \\
\hline $\mathrm{C} 11$ & 100 & 100 & 100 & 0.87 & 0.56 & 0.44 & 3.89 & 13.13 & 10.22 & 3.8 & 4.18 & 3.06 & 769.17 & 1731.67 & 1328.61 \\
\hline $\mathrm{C} 12$ & 100 & 100 & 100 & 0.93 & 0.54 & 0.43 & 12.41 & 7.97 & 9.83 & 7.44 & 4.87 & 3.03 & 1985.78 & 1283.89 & 1286.11 \\
\hline $\mathrm{C} 13$ & 100 & 100 & 100 & 0.83 & 0.5 & 0.51 & 13.83 & 9.88 & 9.08 & 8.71 & 3.84 & 2.83 & 2254.17 & 1372.5 & 1191.67 \\
\hline $\mathrm{C} 14$ & 100 & 93.33 & 100 & 1 & 0.52 & 0.46 & 8.86 & 9.36 & 9.15 & 3.15 & 2.41 & 2.52 & 1200.67 & 1103.73 & 1166.5 \\
\hline $\mathrm{C} 15$ & 100 & 100 & 100 & 0.93 & 0.56 & 0.47 & 10.35 & 6.12 & 6.79 & 4.13 & 1.97 & 1.29 & 1447.83 & 809.33 & 807.44 \\
\hline $\mathrm{C} 16$ & 93.33 & 86.67 & 80 & 0.56 & 0.47 & 0.31 & 10.08 & 8.78 & 6.25 & 3.56 & 3.69 & 1.15 & 1270.00 & 1118.44 & 591.33 \\
\hline $\mathrm{C} 17$ & 100 & 100 & 100 & 0.49 & 0.47 & 0.38 & 9.23 & 8.43 & 6.2 & 4.28 & 3.67 & 2.42 & 1351.33 & 1209.33 & 861.83 \\
\hline $\mathrm{C} 18$ & 100 & 93.33 & 100 & 0.48 & 0.41 & 0.41 & 7.38 & 6.73 & 7.26 & 3.69 & 2.62 & 3.07 & 1107.33 & 885.23 & 1033.5 \\
\hline $\mathrm{C} 19$ & 100 & 100 & 93.33 & 0.9 & 0.51 & 0.37 & 16.28 & 9.97 & 7.32 & 8.67 & 2.92 & 2.17 & 2494.50 & 1289.00 & 900.84 \\
\hline $\mathrm{C} 20$ & 100 & 100 & 100 & 0.97 & 0.51 & 0.51 & 11.73 & 9.06 & 5.94 & 6.75 & 4 & 2.04 & 1848.61 & 1305.83 & 798.33 \\
\hline $\mathrm{C} 21$ & 100 & 93.33 & 100 & 0.8 & 0.62 & 0.58 & 9.93 & 6.29 & 8.36 & 6.15 & 2.58 & 3.18 & 1607.83 & 837.72 & 1153.67 \\
\hline $\mathrm{C} 22$ & 100 & 100 & 93.33 & 0.93 & 0.53 & 0.43 & 18.19 & 15.96 & 8.44 & 9.62 & 5.67 & 2.12 & 2780.67 & 2162.67 & 968.00 \\
\hline $\mathrm{C} 23$ & 100 & 93.33 & 100 & 0.8 & 0.48 & 0.57 & 14.34 & 8.02 & 7.61 & 7.78 & 3.15 & 2.78 & 2211.94 & 1032.22 & 1039.17 \\
\hline $\mathrm{C} 24$ & 100 & 100 & 93.33 & 1 & 0.67 & 0.44 & 16.58 & 8.51 & 10.75 & 8.32 & 5.14 & 2.86 & 2489.83 & 1365 & 1247.61 \\
\hline $\mathrm{C} 25$ & 100 & 93.33 & 80 & 0.8 & 0.49 & 0.42 & 15.5 & 6.05 & 5.58 & 8.1 & 4.77 & 2.22 & 2360.00 & 989.28 & 627.56 \\
\hline C26 & 100 & 100 & 100 & 1 & 0.71 & 0.63 & 11.05 & 5.35 & 4.01 & 7.02 & 2.83 & 2.16 & 1807.67 & 817.5 & 617.22 \\
\hline $\mathrm{C} 27$ & 60 & 73.33 & 40 & 0.24 & 0.27 & 0.13 & 8.57 & 9.21 & 5 & 5.65 & 4.23 & 1.75 & 842.67 & 986.00 & 267.67 \\
\hline C28 & 93.33 & 93.33 & 100 & 0.9 & 0.48 & 0.57 & 11.45 & 12.75 & 6.12 & 6.12 & 4.61 & 1.51 & 1625.33 & 1634.67 & 763.33 \\
\hline C29 & 100 & 80 & 100 & 0.9 & 0.41 & 0.47 & 14.33 & 12.95 & 9.59 & 7.79 & 3.00 & 2.83 & 2212.00 & 1304.33 & 1242.22 \\
\hline C30 & 100 & 93.33 & 93.33 & 0.83 & 0.57 & 0.47 & 12.66 & 9.42 & 8.48 & 5.73 & 4.77 & 3.11 & 1838.89 & 1313.78 & 1083.44 \\
\hline C31 & 73.33 & 53.33 & 86.67 & 0.34 & 0.19 & 0.32 & 12.99 & 8.64 & 8.03 & 6.43 & 2.88 & 2.32 & 1370.83 & 634.22 & 871.33 \\
\hline C32 & 100 & 100 & 100 & 0.48 & 0.52 & 0.42 & 12.66 & 10.02 & 9.37 & 3.84 & 3.79 & 2 & 1650.17 & 1381.00 & 1136.67 \\
\hline C33 & 100 & 100 & 100 & 0.93 & 0.73 & 0.5 & 8.66 & 7.39 & 8.47 & 4.34 & 3.04 & 3.19 & 1300.22 & 1042.50 & 1165.17 \\
\hline C34 & 86.67 & 80 & 86.67 & 0.43 & 0.3 & 0.34 & 10.99 & 10.3 & 8.15 & 3.66 & 2.31 & 1.68 & 1271.33 & 1015.33 & 859.33 \\
\hline C35 & 100 & 100 & 100 & 0.76 & 0.48 & 0.46 & 9.22 & 7.1 & 7.13 & 3.47 & 1.71 & 1.69 & 1269.33 & 880.56 & 881.50 \\
\hline C36 & 86.67 & 93.33 & 86.67 & 0.34 & 0.4 & 0.28 & 12.68 & 9.78 & 7.3 & 6.71 & 3.81 & 1.53 & 1650.67 & 1298.67 & 762.00 \\
\hline C37 & 100 & 100 & 100 & 0.83 & 0.56 & 0.54 & 11.81 & 10.7 & 9.43 & 6.6 & 4.22 & 3.12 & 1840.83 & 1491.83 & 1254.44 \\
\hline C38 & 93.33 & 100 & 86.67 & 0.42 & 0.46 & 0.34 & 12.24 & 10.12 & 11.23 & 5.68 & 4.75 & 2.57 & 1659.06 & 1486.83 & 1205.5 \\
\hline C39 & 93.33 & 80 & 93.33 & 0.51 & 0.31 & 0.38 & 13.78 & 9.52 & 10.99 & 7.17 & 4.45 & 2.24 & 1976.33 & 1090.17 & 1238.67 \\
\hline $\mathrm{C} 40$ & 100 & 93.33 & 86.67 & 1 & 0.49 & 0.4 & 8.69 & 8.34 & 5.67 & 5.26 & 3.43 & 1.81 & 1394.67 & 1094.83 & 653.61 \\
\hline C41 & 100 & 100 & 100 & 0.97 & 0.63 & 0.49 & 8.91 & 6.41 & 8.89 & 7.9 & 5.1 & 3.9 & 1681.33 & 1151.33 & 1278.67 \\
\hline $\mathrm{C} 42$ & 100 & 100 & 100 & 0.57 & 0.51 & 0.47 & 6.71 & 4.83 & 5.55 & 4.94 & 3.33 & 2.51 & 1165.00 & 816.00 & 806.00 \\
\hline C43 & 93.33 & 93.33 & 100 & 0.73 & 0.41 & 0.41 & 6.43 & 3.41 & 3.86 & 2.41 & 0.69 & 1.15 & 838.89 & 380.78 & 500.56 \\
\hline C44 & 66.67 & 100 & 100 & 0.6 & 0.53 & 0.49 & 8.07 & 9.47 & 9.25 & 4.21 & 4.58 & 3.99 & 880.83 & 1405.33 & 1324 \\
\hline $\mathrm{C} 45$ & 80 & 60 & 53.33 & 0.28 & 0.4 & 0.25 & 8.5 & 6.17 & 8.56 & 7.64 & 3.92 & 4.33 & 1357.33 & 636.53 & 663.33 \\
\hline C46 & 100 & 100 & 100 & 0.6 & 0. & 0. & 5.75 & 5.53 & 6.05 & 4.87 & 4.12 & 3.22 & 1061.5 & 965.72 & 927.17 \\
\hline C47 & 100 & 100 & 100 & 0.56 & 0.48 & 0.43 & 9.49 & 10.93 & 10.98 & 3.54 & 3.00 & 2.08 & 1303.33 & 1393.33 & 1306.33 \\
\hline C48 & 100 & 100 & 100 & 0.9 & 0.47 & 0.49 & 9.24 & 7.31 & 6.11 & 2.71 & 1.75 & 1.55 & 1195.33 & 905.67 & 766.00 \\
\hline C49 & 93.33 & 86.67 & 80 & 0.87 & 0.46 & 0.39 & 7.19 & 7.22 & 6.93 & 2.38 & 2.05 & 1.22 & 884.17 & 810.22 & 652.09 \\
\hline C50 & 100 & 86.67 & 86.67 & 0.42 & 0.43 & 0.42 & 6.54 & 4.59 & 5.76 & 3.04 & 2.6 & 2.26 & 958.67 & 649.33 & 719.5 \\
\hline C51 & 100 & 86.67 & 93.33 & 0.8 & 0.44 & 0.41 & 7.35 & 8.06 & 7.5 & 3.04 & 2.09 & 1.53 & 1039 & 876.22 & 850.13 \\
\hline C52 & 100 & 93.33 & 93.33 & 0.5 & 0.47 & 0.47 & 5.57 & 5.03 & 4.35 & 4.91 & 2.61 & 2.4 & 1048.17 & 722.89 & 636.00 \\
\hline C53 & 100 & 80 & 100 & 0.47 & 0.42 & 0.41 & 9.89 & 7.31 & 6.95 & 3.46 & 3.93 & 2.02 & 1334.67 & 873.17 & 896.83 \\
\hline C54 & 93.33 & 100 & 100 & 0.59 & 0.5 & 0.44 & 6.98 & 6.13 & 8.73 & 3.24 & 2.09 & 4.00 & 959.33 & 822.00 & 1272.5 \\
\hline C55 & 100 & 93.33 & 93.33 & 0.63 & 0.4 & 0.33 & 7.43 & 7.24 & 6.24 & 3.31 & 2.79 & 1.88 & 1074 & 950.67 & 746.67 \\
\hline Bambey 21 & 100 & 46.67 & 40 & 0.17 & 0.21 & 0.16 & 9.8 & 5.24 & 3.85 & 3.32 & 1.24 & 1.18 & 1311.67 & 295.11 & 198.67 \\
\hline CB46 & 80 & 93.33 & 93.33 & 0.67 & 0.66 & 0.42 & 8.24 & 7.51 & 7.76 & 4.44 & 2.74 & 1.88 & 1014.67 & 949.56 & 902.06 \\
\hline IT93K-503-1 & 60 & 93.33 & 93.33 & 0.47 & 0.77 & 0.49 & 3.72 & 4.38 & 5.64 & 1.77 & 1.36 & 1.42 & 329.33 & 530.67 & 651.78 \\
\hline Maximum & 100 & 100 & 100 & 1 & 0.77 & 0.63 & 18.19 & 15.96 & 11.23 & 9.62 & 5.67 & 4.33 & 2780.67 & 2162.67 & 1328.61 \\
\hline Minimum & 60 & 46.67 & 40 & 0.17 & 0.19 & 0.13 & 3.72 & 3.41 & 3.85 & 1.77 & 0.69 & 1.13 & 329.33 & 295.11 & 198.67 \\
\hline Mean & 95.29 & 92.3 & 91.15 & 0.68 & 0.47 & 0.41 & 10.6 & 8.2 & 7.45 & 5.34 & 3.17 & 2.23 & 1530.82 & 1057.1 & 891.18 \\
\hline SD & 9.91 & 11.63 & 14.31 & 0.22 & 0.12 & 0.1 & 3.29 & 2.37 & 1.87 & 1.95 & 1.14 & 0.78 & 521.68 & 331.16 & 274.34 \\
\hline$F$ & $14.77^{* * * *}$ & $5.36^{* * *}$ & $7.16^{\cdots *}$ & $2.90^{* * * *}$ & $2.28^{* * * *}$ & $4.03^{\cdots \cdots}$ & $11.07^{* * * *}$ & $6.88^{* * *}$ & $4.75^{* * * *}$ & $6.49^{* * * *}$ & $3.64^{* * * *}$ & $4.96^{* * *}$ & $8.84^{* * * *}$ & $4.80^{* * * *}$ & $5.64^{* * * *}$ \\
\hline Tukeyo.os & 0.19 & 0.17 & 0.14 & 0.35 & 0.44 & 0.39 & 3.32 & 3.03 & 2.88 & 2.57 & 2.00 & 1.18 & 589.69 & 507.85 & 388.28 \\
\hline
\end{tabular}

stress 1 and 2 correspond to the use of PEG-6000 osmotic for obtaining a potential of -0.75 bars and -1.5 bars, respectively. Dark gray or ${ }^{* * *}$ -

significant differences at level $\mathrm{p}<0.001$; gray - significant differences at level $\mathrm{p}<0.01$; light gray - significant differences at level $\mathrm{p}<0.05$;

white/clear - no significant differences.

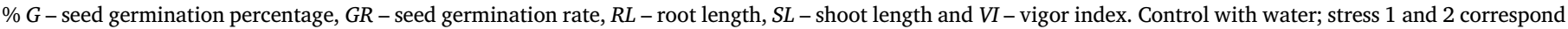

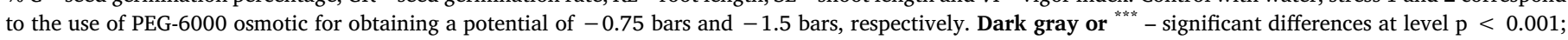
gray - significant differences at level p $<0.01$; light gray - significant differences at level $\mathrm{p}<0.05$; white/clear - no significant differences. 
Table 3

Statistical analysis of seed germination, seedling emergence and proline content evaluated in the 58 studied cowpea genotypes under drought stress conditions. Means were analysed with one-way and two-way ANOVA followed by Tukey's test ( $n=3$ to $\% G, G R, V I$ and $n=15$ to $R L$ and $S L$ and proline content).

\begin{tabular}{lllll}
\hline Treatment & Source & $D F$ & $F$ ratio & Prob $>F$ \\
\hline$\% \boldsymbol{G}$ & Genotype & 57 & 5.968 & $<0.001$ \\
& Treatment & 2 & 6.330 & 0.002 \\
& Genotype * Treatment & 114 & 1.523 & 0.002 \\
$\boldsymbol{G R}$ & Genotype & 57 & 20.427 & $<0.001$ \\
& Treatment & 2 & 495.982 & $<0.001$ \\
& Genotype * Treatment & 114 & 4.754 & $<0.001$ \\
$\boldsymbol{R} \boldsymbol{L}$ & Genotype & 57 & 14.680 & $<0.001$ \\
& Treatment & 2 & 187.136 & $<0.001$ \\
& Genotype * Treatment & 114 & 4.472 & $<0.001$ \\
$\boldsymbol{S L}$ & Genotype & 57 & 9.367 & $<0.001$ \\
& Treatment & 2 & 415.854 & $<0.001$ \\
& Genotype * Treatment & 114 & 3.352 & $<0.001$ \\
VI & Genotype & 57 & 11.893 & $<0.001$ \\
& Treatment & 2 & 26.131 & $<0.001$ \\
& Genotype * Treatment & 114 & 4.287 & $<0.001$ \\
Proline content & Genotype & 57 & 10.865 & $<0.001$ \\
& Treatment & 2 & 78.039 & $<0.001$ \\
& Genotype * Treatment & 114 & 2.928 & $<0.001$ \\
& & &
\end{tabular}

$\% G$ - seed germination percentage, $G R$ - seed germination rate, $R L$ - root length, $S L$ - shoot length and VI - vigor index.

conditions, but using mature plants, revealed Bambey 21 as highly susceptible, CB46 as moderately susceptible and IT93K-503-1 as highly tolerant genotypes (Hamidou et al., 2007; Muchero et al., 2010, 2008). This classification was previously confirmed by us, using different physiological and biochemical approaches on drought-stressed mature plants (unpublished data). The results here presented revealed that a similar trend was observed at germination/seedling stages, suggesting that the mentioned genotypes (Bambey 21, CB46 and IT93K-503-1) could be used as susceptible/tolerant reference genotypes. On the other hand, several studies in other crop species (e.g. Beshir et al., 2016; Dodig et al., 2015), including in cowpea (Singh et al., 1999), have revealed a close correspondence of drought tolerance observed in seedlings and reproductive stage plants. Different seed germination and seedling emergence capacities were displayed by distinct cowpea genotypes under stress conditions. As a large proportion of cowpea genotypes did not present any difference on seed germination percentage between treatments, PEG-6000 treatments could not have a strong influence during this stage. According to Mickky and Aldesuquy (2017), the use of PEG-6000 causes a delay in seed germination, as it happens naturally in the drought, but the seed germination percentage is not affected. In the present work, the decrease of seed germination rate was indeed more evident that the decline in germination (\%, six days after sowing) and one of the most pronounced parameters under study. This result is in accordance with other cowpea studies, where the seed germination rate $(G R)$ also decreased with drought stress induced by PEG-6000 (Araújo et al., 2018; Ferreira et al., 2017; Murillo-Amador et al., 2002). Several cowpea genotypes revealed significant alterations in their germination with PEG-6000 treatments, while others were not so affected, suggesting that distinct genotypes could be differently disturbed by drought. This variability can be considered as a valuable tool for screening cowpea genotypes more tolerant and adapted to climate change. From the assayed cowpea genotypes, 16 cowpea genotypes, including the moderately susceptible CB46, revealed non-significant changes on both germination parameters. These results can be a valuable information about the possible drought tolerant genotypes.

Root length is pointed as another key trait for the selection and differentiation of drought tolerant genotypes, due to the role of roots in providing water and maintaining an adequate water balance in plants.
Table 4

Proline content evaluated in the 58 studied cowpea genotypes under drought stress induced by PEG-6000 and control. For reference, maximum, minimum, mean, $F$-value and Tukey's test (significance level of 0.05$)$ values are indicated. Means $(n=15)$ were analysed with one-way ANOVA followed by Tukey's test (significance level of 0.05).

\begin{tabular}{|c|c|c|c|}
\hline \multirow[b]{2}{*}{ Code } & \multicolumn{3}{|c|}{ Proline content } \\
\hline & Control & Stress 1 & Stress 2 \\
\hline $\mathrm{C} 1$ & 0.49 & 0.33 & 0.41 \\
\hline $\mathrm{C} 2$ & 0.21 & 0.33 & 0.35 \\
\hline $\mathrm{C} 3$ & 0.73 & 0.30 & 0.27 \\
\hline $\mathrm{C} 4$ & 0.15 & 0.26 & 0.47 \\
\hline C5 & 0.21 & 0.31 & 0.38 \\
\hline $\mathrm{C} 6$ & 0.15 & 0.54 & 0.91 \\
\hline $\mathrm{C} 7$ & 0.14 & 0.28 & 0.43 \\
\hline $\mathrm{C} 8$ & 0.29 & 0.40 & 0.30 \\
\hline C9 & 0.17 & 0.06 & 0.03 \\
\hline $\mathrm{C} 10$ & 0.23 & 0.56 & 0.35 \\
\hline $\mathrm{C} 11$ & 0.65 & 0.38 & 0.37 \\
\hline $\mathrm{C} 12$ & 0.14 & 0.26 & 0.28 \\
\hline $\mathrm{C} 13$ & 0.17 & 0.42 & 0.23 \\
\hline C14 & 0.17 & 0.38 & 0.8 \\
\hline $\mathrm{C} 15$ & 0.58 & 1.09 & 0.99 \\
\hline C16 & 0.19 & 0.26 & 0.35 \\
\hline $\mathrm{C} 17$ & 0.26 & 0.28 & 0.24 \\
\hline $\mathrm{C} 18$ & 0.11 & 0.24 & 0.32 \\
\hline C19 & 0.16 & 0.35 & 0.77 \\
\hline $\mathrm{C} 20$ & 0.18 & 0.41 & 0.49 \\
\hline $\mathrm{C} 21$ & 0.19 & 0.21 & 0.24 \\
\hline $\mathrm{C} 22$ & 0.13 & 0.13 & 0.22 \\
\hline $\mathrm{C} 23$ & 0.12 & 0.14 & 0.14 \\
\hline $\mathrm{C} 24$ & 0.14 & 0.12 & 0.21 \\
\hline $\mathrm{C} 25$ & 0.20 & 0.40 & 0.74 \\
\hline $\mathrm{C} 26$ & 0.16 & 0.32 & 0.40 \\
\hline $\mathrm{C} 27$ & 0.13 & 0.25 & 0.31 \\
\hline $\mathrm{C} 28$ & 0.15 & 0.15 & 0.30 \\
\hline $\mathrm{C} 29$ & 0.15 & 0.18 & 0.20 \\
\hline $\mathrm{C} 30$ & 0.11 & 0.17 & 0.32 \\
\hline $\mathrm{C} 31$ & 0.29 & 0.24 & 0.23 \\
\hline C32 & 0.54 & 0.43 & 0.52 \\
\hline $\mathrm{C} 33$ & 0.37 & 0.41 & 0.42 \\
\hline C34 & 0.17 & 0.31 & 0.55 \\
\hline C35 & 0.42 & 0.55 & 0.68 \\
\hline C36 & 0.19 & 0.24 & 0.46 \\
\hline C37 & 0.26 & 0.26 & 0.39 \\
\hline C38 & 0.19 & 0.20 & 0.34 \\
\hline C39 & 0.16 & 0.92 & 0.4 \\
\hline $\mathrm{C} 40$ & 0.31 & 0.42 & 0.50 \\
\hline C41 & 0.30 & 0.53 & 0.45 \\
\hline $\mathrm{C} 42$ & 0.34 & 0.42 & 0.35 \\
\hline $\mathrm{C} 43$ & 0.59 & 0.65 & 1.10 \\
\hline C44 & 0.38 & 0.56 & 0.78 \\
\hline C45 & 0.36 & 0.34 & 0.25 \\
\hline $\mathrm{C} 46$ & 0.25 & 0.36 & 0.41 \\
\hline $\mathrm{C} 47$ & 0.42 & 0.41 & 0.64 \\
\hline $\mathrm{C} 48$ & 0.30 & 0.53 & 0.84 \\
\hline C49 & 0.16 & 0.34 & 0.8 \\
\hline $\mathrm{C} 50$ & 0.32 & 0.46 & 0.51 \\
\hline $\mathrm{C} 51$ & 0.13 & 0.33 & 0.55 \\
\hline $\mathrm{C} 52$ & 0.20 & 0.57 & 0.54 \\
\hline C53 & 0.15 & 0.47 & 0.57 \\
\hline C54 & 0.08 & 0.46 & 0.76 \\
\hline C55 & 0.23 & 0.44 & 0.67 \\
\hline Bambey 21 & 0.52 & 0.59 & 0.42 \\
\hline CB46 & 0.32 & 0.27 & 0.32 \\
\hline IT93K-503-1 & 0.62 & 0.89 & 1.38 \\
\hline Maximum & 0.73 & 1.09 & 1.38 \\
\hline Minimum & 0.08 & 0.06 & 0.03 \\
\hline Mean & 0.27 & 0.38 & 0.48 \\
\hline SD & 0.15 & 0.19 & 0.25 \\
\hline$F$ & $14.77^{* * *}$ & $5.36^{* * *}$ & $7.16^{* * *}$ \\
\hline Tukeyo.os & 0.3 & 0.26 & 0.31 \\
\hline
\end{tabular}

Control with water; stress 1 and 2 correspond to the use of PEG-6000 osmotic for obtaining a potential of -0.75 bars and -1.5 bars, respectively.

Dark gray or ${ }^{* * *}$ - significant differences at level $\mathrm{p}<0.001$; gray - significant differences at level $\mathrm{p}<0.01$; light gray - significant differences at level $\mathrm{p}<0.05$; white/clear - no significant differences. 
Roots are thus deeply affected when plants are subjected to water stress and are the first plant organs suffering from water stress during seedlings development (Silva and Matos, 2016; Trachsel et al., 2013). Water stress causes decrease of cellular division, increase of rigidification of cell wall resulting in a reduction of root elongation and root-hair development during germination (Muscolo et al., 2014; Silva and Matos, 2016). In general, with increasing of water stress, cowpea seedlings presented a higher decrease of root length than shoot length. This result is in agreement with others studies that verified that the symptoms observed in shoots are normally softer and can be delayed relative to the root (Silva and Matos, 2016). The C6 and Bambey 21 (susceptible reference) genotype (together with C20 and C25 genotypes) were the most affected under drought stress conditions, indicating a higher susceptibility to osmotic stress. In contrast, the drought-tolerant reference (IT93K-503-1) and several other genotypes did not present significant differences between treatments in root length and shoot length, suggesting them as drought tolerant genotypes.

Seedling vigor index is another important parameter that combines seed germination percentage and seedling growth data. The values obtained for this parameter decreased in all genotypes with increasing water stress, except for the tolerant reference (IT93K-503-1) and also C11 and C54 genotypes. In all these cowpea genotypes, the vigor index values increased with water stress conditions, indicating that they display some capacity to tolerate drought. Furthermore, C11 and C54 could be so adapted to water limiting conditions that seem to have a preference for water scarcity during its development. Furthermore, the moderately susceptible reference (CB46) and other four genotypes (C33, C14, C46 and C47) were the least affected by drought stress presenting the lowest decrease of vigor index in the three treatments, being also considered as possible drought tolerant genotypes. On the other hand, a drastic decrease on vigor was observed in the susceptible reference (Bambey 21), similar to decreases observed for other three cowpea genotypes (C6, C25 and C26), followed by others genotypes such as C19, C20 and C22. These results suggest higher susceptibility of these genotypes to drought. Moraes et al. (2005) in common bean (Phaseolus vulgaris L.) and Cokkizgin (2013) in pea (Pisum sativum L.) also reported a decrease of seedling vigor index with the increasing of
PEG-6000 concentrations. The same result was also obtained in cowpea by Jain and Saxena (2016) using PEG-4000.

As proline is one of the compatible solutes that plants accumulate under water stress being the accumulation of this osmolyte correlated with stress tolerance (Anjum et al., 2011). Proline accumulation is commonly associated with the increase of cell osmotic potential, facilitating the water absorption (Ashraf and Foolad, 2007; Toscano et al., 2016), but can also reduce cells injury (Anjum et al., 2011). Our data agree with proline protective role, as proline content generally increased in all genotypes under stress conditions, presenting the tolerant reference (IT93K-503-1) the highest contents. A significant increase in proline with drought imposition was also observed for other 13 cowpea genotypes. Other studies revealed similar increases in other cowpea genotypes (Cavalcanti et al., 2004; Goufo et al., 2017; Merwad et al., 2018), as well in other species, such as in soybean (Glycine max L. Merr.; Mwenye et al., 2016) or chickpea (Cicer arietinum L.; Mafakheri et al., 2010). On the other hand, in the present study some genotypes did not reveal any difference in the proline content under drought conditions, as the moderately susceptible reference CB46 (together with C8, C32 and C42). In others genotypes, the proline content decreased with drought stress, such as in the highly susceptible reference Bambey 21 (and also in C1, C3, C9, C31 and C45).

Although a common trend is observed for all cowpea genotypes under drought stress (germination and seedling development alterations), each genotype displays a more specific response, probably due to the processes to which they are more susceptible/tolerant. For example, C21 genotype is greatly affected in shoot development, while C33 is significantly affected in seed germination rate. The most susceptible genotypes will be affected in most of evaluated parameters, as detected for Bambey 21, while the most tolerant will be unaffected, like observed for IT93K-503-1. Taking this into consideration, our data suggest that the most tolerant cowpea genotypes were C16, C18, C44, C46, C47, $\mathrm{C} 50, \mathrm{C} 53$, and in a lesser extent C38, C43, C52. In contrast, the most susceptible genotypes seem to be C6, C22, C24, C25, and in a lesser extent C7, C20, C28, C40. A PCA performed with normalized data (ratio between the highest drought stress imposition and control) showed that the reference genotypes Bambey 21 and IT93K-503-1 had divergent

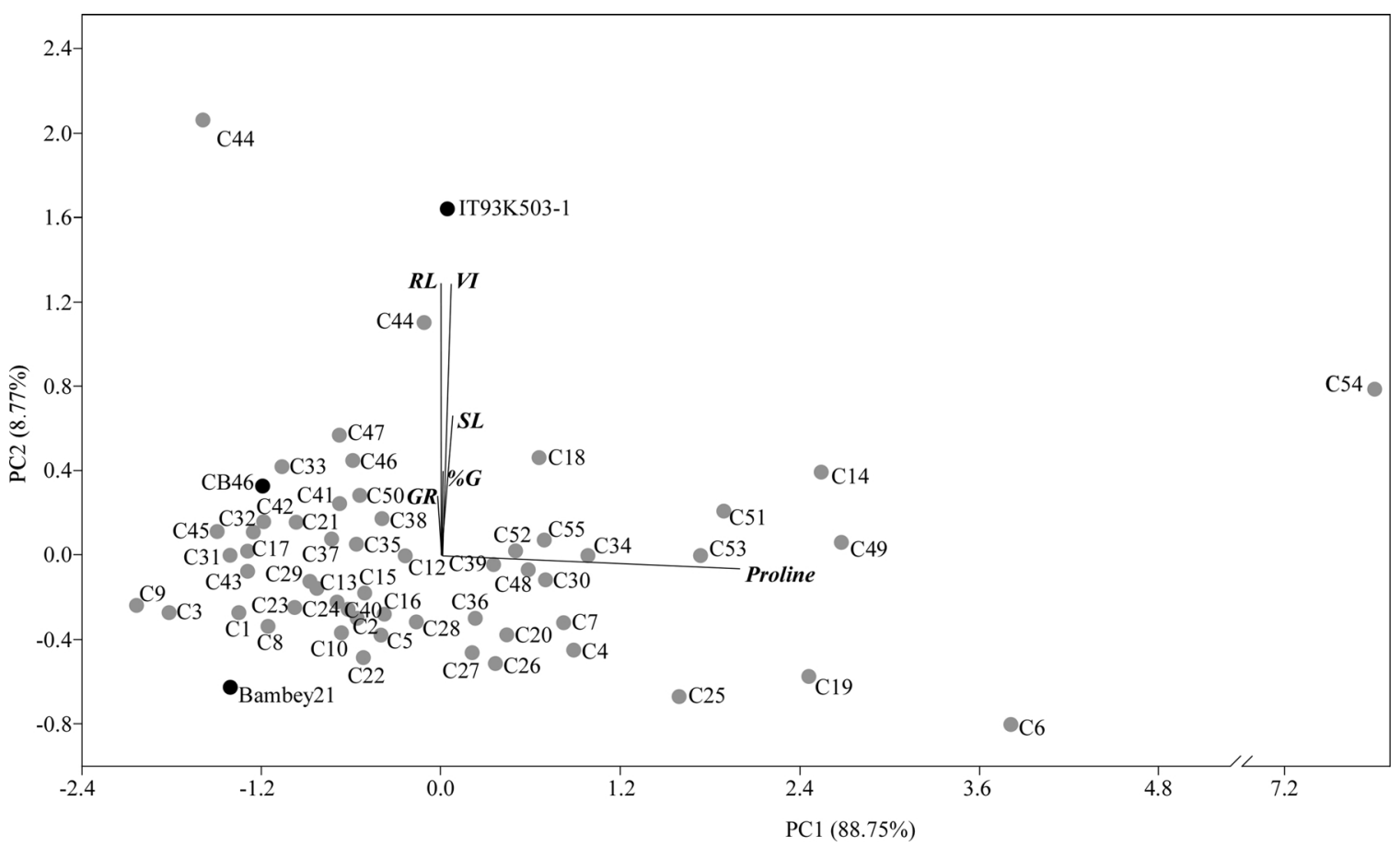

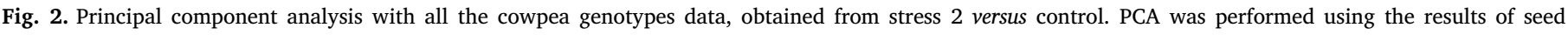
germination percentage $(\% G)$ and rate $(G R)$, root $(R L)$ and shoot $(S L)$ length, vigor index $(V I)$ and proline content. 
drought responses, corroborating the previous studies of Hamidou et al. (2007) and Muchero et al. (2008, 2010). Close to the tolerant reference (IT93K-503-1) was the genotype C44, and also C18, C46, C47 and C50. Regarding, C11 and C54 genotypes, the PCA revealed that they present a different drought response from all the others genotypes under study, presenting a general increase of studied traits, consistent with drought tolerant genotypes. For other hand, the susceptible reference (Bambey 21) was very close to the genotypes $\mathrm{C} 3$ and $\mathrm{C} 9$.

Most of the evaluated genotypes had been previously included in a genetic diversity study using single nucleotide polymorphisms (SNPs), revealing that they were grouped based on their geographical origin (Carvalho et al., 2017b). The suggested tolerant genotypes C46 (Zambia), C47 (Iran) and C50 (Congo) were considered admixed due they have information from several subpopulations. Probably, these genotypes are the result of introgression of genetic material on other lines and subsequent selection by farmers based on their adaptation to specific environmental conditions, in these cases all tropical and subtropical weather. The other suggested tolerant genotypes (C11, C18 and C44) were from Portugal, Spain and Spain, respectively, and belong to different subpopulations from genetic analysis (Carvalho et al., 2017b). These genotypes could be a source of variability and could be useful for the improvement of new varieties to mitigate the effects of climate change.

\section{Conclusions}

The selection of cowpea (Vigna unguiculata L. Walp.) genotypes welladapted to upcoming climate change (including drought) is a key step for improving crop production. Drought can inhibit the germination and subsequent seedling growth, impairing the crops establishment. Therefore, the germplasm screening at an early growth stage is a reasonable approach for selecting tolerant genotypes to drought conditions. PEG induction is a simple, cost effective and fast method of drought induction allowing to screen a large number of genotypes. Various seed germination and seedling emergence features could be evaluated to have a complete picture of drought responses in an early stage, but root length, vigor index and proline contents were the most consistent and informative, enabling to infer about genotypes drought tolerance. A response variation was identified in this collection of cowpea genotypes that can be further explored by plant breeders. Our results suggest that C11 (Portugal), C18 (Spain), C44 (Ghana), C46 (Zambia), C47 (Iran), C50 (Congo) and C54 (Bulgaria) cowpea genotypes showed a high drought tolerance at germination stage. These accessions could be further used as parents for developing segregating populations for cowpea drought tolerance and to get of new varieties.

\section{Funding}

This study was supported by EUROLEGUME project. This project has received funding from the European Union's Seventh Framework Programme for research, technological development and demonstration under grant agreement no 613781. European Investment Funds by FEDER/COMPETE/POCI - Operational Competitiveness and Internationalization Programme, under Project POCI-01-0145-FEDER006958 and National Funds by FCT - Portuguese Foundation for Science and Technology, under the projects UID/AGR/04033/2013 and UID/AGR/04046/2013.

The funding entities had no role in the design of the study, collection, analysis and interpretation of data, or in writing the manuscript.

\section{Acknowledgements}

The authors would like to thank the seed providing namely, the National Institute for Agrarian and Veterinarian Research (INIAV, Portugal), National Plant Genetic Resources Centre-National Institute for Agricultural and Food Technology Research (CRF-INIA, Spain),
Leibniz Institute of Plant Genetics and Crop Plant Research (IPK, Gatersleben, Germany), the Botanic Garden Meise (Belgium), the University of Perugia (Italy), and the Brazilian Agricultural Research Corporation (EMBRAPA, Brazil) and Professor Timothy J. Close from University of California Riverside and also the spectrophotometer equipment providing by Professor Ana Coimbra.

\section{Appendix A. Supplementary data}

Supplementary material related to this article can be found, in the online version, at doi:https://doi.org/10.1016/j.scienta.2018.11.082.

\section{References}

Abdul-Baki, A.A., Anderson, J.D., 1973. Vigor determination in soybean seed by multiple criteria. Crop Sci. 13, 630-633. https://doi.org/10.2135/cropsci1973. 0011183X001300060013x.

Agbicodo, E.M., Fatokun, C.A., Muranaka, S., Visser, R.G.F., Linden Van Der, C.G., 2009. Breeding drought tolerant cowpea: constraints, accomplishments, and future prospects. Euphytica 167, 353-370. https://doi.org/10.1007/s10681-009-9893-8.

Ahmad, S., Ahmad, R., Ashraf, M.Y., Ashraf, M., Waraich, E.A., 2009. Sunflower (Helianthus Annuus L.) response to drought stress at germination and seedling growth stages. Pak. J. Bot. 41, 647-654.

Anjum, S., Xie, X., Wang, L., 2011. Morphological, physiological and biochemical responses of plants to drought stress. Afr. J. Agric. Res. 6, 2026-2032. https://doi.org/ 10.5897/AJAR10.027.

Araújo, E.D.D.E., Melo, A.S.D.E., Do, M., Rocha, S., 2018. Germination and initial growth of cowpea cultivars under osmotic stress and salicylic acid. Rev. Caatinga 31, 80-89.

Ashraf, M., Foolad, M.R., 2007. Roles of glycine betaine and proline in improving plant abiotic stress resistance. Environ. Exp. Bot. 59, 206-216. https://doi.org/10.1016/j. envexpbot.2005.12.006.

Bates, L.S., 1973. Rapid determination of free proline for water stress studies. Plant Soil 39, 205-207.

Beshir, H.M., Bueckert, R., Sciences, H., 2016. Effect of temporary drought at different growth stages on snap bean pod quality and yield. Afr. Crop Sci. J. 24, 317-330. https://doi.org/10.4314/acsj.v24i3.8.

Bouslama, M., Schapaugh, W.T., 1984. Stress tolerance in soybeans. I. Evaluation of three screening techniques for heat and drought tolerance. Crop Sci. 24, 933-937. https:// doi.org/10.2135/cropsci1984.0011183X002400050026x.

Carvalho, M., Bebeli, P.J., Pereira, G., Castro, I., Egea-Gilabert, C., Matos, M., Lazaridi, E., Duarte, I., Lino-Neto, T., Ntatsi, G., Rodrigues, M., Savvas, D., Rosa, E., Carnide, V., 2017a. European cowpea landraces for a more sustainable agriculture system and novel foods. J. Sci. Food Agric. 97, 4399-4407. https://doi.org/10.1002/jsfa.8378.

Carvalho, M., Muñoz-Amatriaín, M., Castro, I., Lino-Neto, T., Matos, M., Egea-Cortines, M., Rosa, E., Close, T., Carnide, V., 2017b. Genetic diversity and structure of Iberian Peninsula cowpeas compared to world-wide cowpea accessions using high density SNP markers. BMC Genom. 18, 891. https://doi.org/10.1186/s12864-017-4295-0.

Cavalcanti, F.R., Oliveira, J.T.A., Martins-Miranda, A.S., Viégas, R.A., Silveira, J.A.G., 2004. Superoxide dismutase, catalase and peroxidase activities do not confer protection against oxidative damage in salt-stressed cowpea leaves. New Phytol. 163, 563-571. https://doi.org/10.1111/j.1469-8137.2004.01139.x.

Cokkizgin, A., 2013. Effects of hydro and osmo-priming on seed vigor of pea (Pisum sativum L.). Agric. For. Fish. 2 (6), 225-228. https://doi.org/10.11648/j.aff. 20130206.14.

Darkwa, K., Ambachew, D., Mohammed, H., Asfaw, A., Blair, M.W., 2016. Evaluation of common bean (Phaseolus vulgaris L.) genotypes for drought stress adaptation in Ethiopia. Crop J. 4, 367-376. https://doi.org/10.1016/j.cj.2016.06.007.

Dharanguttikar, V.M., Bharud, R.W., Borkar, V.H., 2015. Physiological responses of chickpea genotypes for drought tolerance under induced moisture stress. IJSRP 5, $1-11$.

Dodig, D., Zorić, M., Jović, M., Kandić, V., Stanisavljević, R., Šurlan-Momirović, G., 2015. Wheat seedlings growth response to water deficiency and how it correlates with adult plant tolerance to drought. J. Agric. Sci. 153, 466-480. https://doi.org/10.1017/ S002185961400029X.

Eftekhari, A., Baghizadeh, A., Yaghoobi, M.M., Abdolshahi, R., 2017. Differences in the drought stress response of DREB2 and CAT1 genes and evaluation of related physiological parameters in some bread wheat cultivars. Biotechnol. Biotechnol. Equip. 31, 709-716. https://doi.org/10.1080/13102818.2017.1316214.

Ehlers, J.D., Hall, A.E., 1996. Genotypic classification of cowpea based on responses to heat and photoperiod. Crop Sci. 36, 673-679. https://doi.org/10.2135/cropsci1996. 0011183X003600030026x.

Eloward, H.O., Hall, A.E., 1987. Influence of early and late nitrogen fertilization on yield and nitrogen fixation of cowpea under well-watered and dry field conditions. Field Crops Res. 15, 229-244.

FAOSTAT, 2018. Food and Agriculture Organization of the United Nations - Statistics Division. (Accessed 20 June 2018). http://faostat3.fao.org/browse/Q/QC/E.

Ferreira, A.C.T., Felito, R.A., Da Rocha, A.M., De Carvalho, M.A.C., Yamashita, O.M., 2017. Water and salt stresses on germination of cowpea (Vigna unguiculata cv. brs tumucumaque) seeds. Rev. Caatinga 30 (4), 1009-1016.

Goufo, P., Moutinho-Pereira, J.M., Jorge, T.F., Correia, C.M., Oliveira, M.R., Rosa, E.A.S., António, C., Trindade, H., 2017. Cowpea (Vigna unguiculata L. Walp.) metabolomics: 
osmoprotection as a physiological strategy for drought stress resistance and improved yield. Front. Plant Sci. 8, 1-22. https://doi.org/10.3389/fpls.2017.00586.

Hamidou, F., Zombre, G., Braconnier, S., 2007. Physiological and biochemical responses of cowpea genotypes to water stress under glasshouse and field conditions. J. Agron. Crop Sci. 193, 229-237. https://doi.org/10.1111/j.1439-037X.2007.00253.x.

Hammer, O., Harper, D.A.T., Ryan, P.D., 2001. Past: paleontological statistics software package for education and data analysis. Paleontol. Electron. 4 (1), 1-9.

Hellal, F.A., El-Shabrawi, H.M., Abd El-Hady, M., Khatab, I.A., El-Sayed, S.A.A., Abdelly, C., 2018. Influence of PEG induced drought stress on molecular and biochemical constituents and seedling growth of Egyptian barley cultivars. J. Genet. Eng. Biotechnol. 16, 203-212. https://doi.org/10.1016/j.jgeb.2017.10.009.

Huang, K., Mellor, K.E., Paul, S.N., Lawson, M.J., Mackey, A.J., Timko, M.P., 2012. Global changes in gene expression during compatible and incompatible interactions of cowpea (Vigna unguiculata L.) with the root parasitic angiosperm Striga gesnerioides. BMC Genom. 13, 402. https://doi.org/10.1186/1471-2164-13-402.

Jain, C., Saxena, R., 2016. Varietal differences against PEG induced drought stress in cowpea Chinkita Jain. Octa J. Environ. Res. 4, 58-62.

Kaya, M.D., Okçu, G., Atak, M., Çikili, Y., Kolsarici, Ö., 2006. Seed treatments to overcome salt and drought stress during germination in sunflower (Helianthus annuus L.). Eur. J. Agron. 24, 291-295. https://doi.org/10.1016/j.eja.2005.08.001.

Khodarahmpour, Z., 2011. Genetic analysis of tolerance to heat stress in maize (Zea mays L.). Afr. J. Agric. Res. 6, 2767-2773. https://doi.org/10.5897/AJAR10.798.

Kocheva, K., Georgiev, G., 2003. Evaluation of teh reaction of two contrasting barley (Hordeum vulgare L.) cultivars in response to osmotic stress with PEG 6000. Bulg. J. Plant Physiol. Spec. Issue 2003, 290-294.

Kpoghomou, B.K., Sapra, V.T., Beyl, C.A., 1990. Screening for drought tolerance: soybean germination and its relationship to seedling responses. J. Agron. Crop Sci. 164, 153-159. https://doi.org/10.1111/j.1439-037X.1990.tb00801.x.

Kröner, N., Kotlarski, S., Fischer, E., Lüthi, D., Zubler, E., Schär, C., 2017. Separating climate change signals into thermodynamic, lapse-rate and circulation effects: theory and application to the European summer climate. Clim. Dyn. 48, 3425-3440. https:// doi.org/10.1007/s00382-016-3276-3.

Li, F.L., Bao, W.K., Wu, N., 2011. Morphological, anatomical and physiological responses of Campylotropis polyantha (Franch.) Schindl. seedlings to progressive water stress. Sci. Hortic. (Amsterdam) 127, 436-443. https://doi.org/10.1016/j.scienta.2010.10. 017.

Li, R., Zeng, Y., Xu, J., Wang, Q., Wu, F., Cao, M., Lan, H., Liu, Y., Lu, Y., 2015. Genetic variation for maize root architecture in response to drought stress at the seedling stage. Breed. Sci. 65, 298-307. https://doi.org/10.1270/jsbbs.65.298.

Machado Neto, N.B., Custódio, C.C., Costa, P.R., Dona, F.L., 2006. Deficiência hídrica induzida por diferentes agentes osmóticos na germinação e vigor de sementes de feijão. Rev. Bras. Sementes 28, 142-148. https://doi.org/10.1590/S010131222006000100020 .

Mafakheri, A., Siosemardeh, A., Bahramnejad, B., Struik, P.C., Sohrabi, E., 2010. Effect of drought stress on yield, proline and chlorophyll contents in three chickpea cultivars. Aust. J. Crop Sci. 4, 580-585.

Merwad, A.R.M.A., Desoky, E.S.M., Rady, M.M., 2018. Response of water deficit-stressed Vigna unguiculata performances to silicon, proline or methionine foliar application. Sci. Hortic. (Amsterdam) 228, 132-144. https://doi.org/10.1016/j.scienta.2017.10. 008.

Mickky, B.M., Aldesuquy, H.S., 2017. Impact of osmotic stress on seedling growth observations, membrane characteristics and antioxidant defense system of different wheat genotypes. Egypt. J. Basic Appl. Sci. 4, 47-54. https://doi.org/10.1016/j. ejbas.2016.10.001.

Moraes, G.A.F., Menezes, N.L., Pasqualli, L.L., 2005. Comportamento de sementes de feijão sob diferentes potenciais osmóticos. Ciênc. Rural 35 (4), 776-780. https://doi. org/10.1590/S0103-84782005000400004.

Muchero, W., Ehlers, J.D., Close, T.J., Roberts, P.A., 2009. Mapping QTL for drought stress-induced premature senescence and maturity in cowpea [Vigna unguiculata (L.) Walp.]. Theor. Appl. Genet. 118, 849-863. https://doi.org/10.1007/s00122-0080944-7.

Muchero, W., Ehlers, J.D., Roberts, P.A., 2010. Restriction site polymorphism-based candidate gene mapping for seedling drought tolerance in cowpea [Vigna unguiculata (L.) Walp.]. Theor. Appl. Genet. 120, 509-518. https://doi.org/10.1007/s00122009-1171-6.

Muchero, W., Ehlers, J.D., Roberts, P.A., 2008. Seedling stage drought-induced phenotypes and drought-responsive genes in diverse cowpea genotypes. Crop Sci. 48, 541-552. https://doi.org/10.2135/cropsci2007.07.0397.

Murillo-Amador, B., López-Aguilar, R., Kaya, C., Larrinaga-Mayoral, J., Flores-Hernández, A., 2002. Comparative effects of $\mathrm{NaCl}$ and polyethylene glycol on germination, emergence and seedling growth of cowpea. J. Agron. Crop Sci. 188, 235-247. https://doi.org/10.1046/j.1439-037X.2002.00563.x.

Muscolo, A., Sidari, M., Anastasi, U., Santonoceto, C., Maggio, A., 2014. Effect of PEGinduced drought stress on seed germination of four lentil genotypes. J. Plant Interact. 9, 354-363. https://doi.org/10.1080/17429145.2013.835880.

Mwenye, O.J., van Rensburg, L., van Biljon, A., van der Merwe, R., 2016. The role of proline and root traits on selection for drought-stress tolerance in soybeans: a review. S. Afr. J. Plant Soil 33, 245-256. https://doi.org/10.1080/02571862.2016.1148786.

Ravelombola, W.S., Shi, A., Weng, Y., Clark, J., Motes, D., Chen, P., Srivastava, V., 2017. Evaluation of salt tolerance at germination stage in cowpea [Vigna unguiculata (L.) Walp]. HortScience 52, 1168-1176. https://doi.org/10.21273/HORTSCI12195-17.

Silva, P., Matos, M., 2016. Assessment of the impact of Aluminum on germination, early growth and free proline content in Lactuca sativa L. Ecotoxicol. Environ. Saf. 131, 151-156. https://doi.org/10.1016/j.ecoenv.2016.05.014.

Singh, B.B., Mai-Kodomi, Y., Terao, T., 1999. A simple screening method for drought tolerance in cowpea. Indian J. Genet. Plant Breed. 59, 211-220.

Steiner, F., Zuffo, A.M., Zoz, T., Zoz, A., Zoz, J., 2017. Drought tolerance of wheat and black oat crops at early stages of seedling growth. SCAP 40 (3), 576-586. https://doi. org/10.19084/RCA16118.

Timko, M.P., Singh, B.B., 2008. Cowpea, a multifunctional legume. In: Moore, P.H., Ming, R. (Eds.), Genomics of Tropical Crop Plants. Springer Science + Business Media LLC, New York, pp. 227-258. https://doi.org/10.1007/s13398-014-0173-7.2.

Toscano, S., Farieri, E., Ferrante, A., Romano, D., 2016. Physiological and biochemical responses in two ornamental shrubs to drought stress. Front. Plant Sci. 7, 645. https://doi.org/10.3389/fpls.2016.00645.

Trachsel, S., Kaeppler, S.M., Brown, K.M., Lynch, J.P., 2013. Maize root growth angles become steeper under low N conditions. Field Crops Res. 140, 18-31. https://doi. org/10.1016/j.fcr.2012.09.010.

Vieira, R.D., Tekrony, D.M., Egli, D.B., 1991. Effect of drought stress on soybean seed germination and vigor. J. Seed Technol. 15, 12-21.

Wu, C., Wang, Q., Xie, B., Wang, Z., Cui, J., Hu, T., 2011. Effects of drought and salt stress on seed germination of three leguminous species. Afr. J. Biotechnol. 10, 17954-17961. https://doi.org/10.5897/AJB11.2018.

Yan, M., 2015. Seed priming stimulate germination and early seedling growth of Chinese cabbage under drought stress. S. Afr. J. Bot. 99, 88-92. https://doi.org/10.1016/j. sajb.2015.03.195. 